\title{
Children with congenital heart disease in COVID-19 pandemic times: an integrative review
}

\author{
Criança com cardiopatia congênita em tempos de pandemia de COVID-19: revisão integrativa \\ Niño con cardiopatía congénita en tiempos de la pandemia de COVID-19: revisión integradora
}

Aline Cerqueira Santos Santana da Silva' ORCID: 0000-0002-8119-3945

Fernanda Garcia Bezerra Góes' ORCID: 0000-0003-3894-3998

Liliane Faria da Silva" ORCID: 0000-0002-9125-1053

Laura Johanson da Silva"' ORCID: 0000-0002-4439-9346

Michelly Cristynne Souza Bonifácio' ORCID: 0000-0001-7771-6507

Yasminn Canella Cabral Banjar Coelho' ORCID: 0000-0001-7774-7573

'Universidade Federal Fluminense. Rio das Ostras, Rio de Janeiro, Brazil. "Universidade Federal Fluminense. Niterói, Rio de Janeiro, Brazil. I"Universidade Federal do Estado do Rio de Janeiro. Rio de Janeiro, RJ, Brazil.

How to cite this article: Silva ACSS, Góes FGB, Silva LF, Silva LJ, Bonifácio MCS, Coelho YCCB. Children with congenital heart disease in

COVID-19 pandemic times: an integrative review. Rev Bras Enferm. 2022;75(1):e20201033. https://doi.org/10.1590/0034-7167-2020-1033

Corresponding author:

Aline Cerqueira Santos Santana da Silva E-mail: alinecer204@gmail.com

EDITOR IN CHIEF: Dulce Barbosa ASSOCIATE EDITOR: Priscilla Broca

Submission: 09-17-2020

Approval: 04-27-2021

\section{ABSTRACT}

Objective: to identify the scientific production in health about children with congenital heart disease in COVID-19 pandemic times. Method: this is an integrative review, carried out in June 2020 in the information resources Latin American and Caribbean Literature in Health Sciences (LILACS), National Library of Medicine, National Institutes of Health (PubMed), Scientific Electronic Library Online Journal Portal (SciELO) and Brazilian Institute of Information Science and Technology (Oasis Ibict). Results: 14 studies composed this review. Most studies pointed to tests, interventional procedures and surgery for children with heart disease in pandemic times; others discussed possible complications of COVID-19 among children with congenital heart disease. Conclusion: the incipient production of studies and the weak level of evidence denote an important knowledge gap so far, highlighting the need for studies with strong scientific evidence for the formulation of care guidelines aimed at children with heart disease.

Descriptors: Child Health; Child; Congenital Heart Diseases; Coronavirus Infections; Pandemic.

\section{RESUMO}

Objetivo: identificar a produção científica da área da saúde acerca da criança com cardiopatia congênita em tempos de pandemia de COVID-19. Método: revisão integrativa, realizada em junho de 2020 nos recursos informacionais Literatura Latino Americana e do Caribe em Ciências da Saúde (LILACS), National Library of Medicine National Institutes of Health (PubMed), Portal de Revistas Scientific Eletronic Library Online (SciELO) e Instituto Brasileiro de Informaação Ciência e Tecnologia (Oasis Ibict). Resultados: 14 estudos compuseram esta revisão. A maioria dos estudos apontava para a realização de exames, procedimentos intervencionistas e cirurgia da criança cardiopata em tempos de pandemia; outros teceram considerações sobre possíveis complicações da COVID-19 entre crianças com cardiopatia congênita. Conclusão: a incipiente produção de estudos e o fraco nível de evidência denotam importante lacuna de conhecimento até o momento, ressaltando a necessidade de estudos com forte evidência científica para a formulação de diretrizes assistenciais voltadas à criança cardiopata.

Descritores: Saúde da Criança; Criança; Cardiopatias Congênitas; Infecções por Coronavírus; Pandemia.

\section{RESUMEN}

Objetivo: identificar la producción científica en el área de la salud sobre niños con cardiopatías congénitas en tiempos de la pandemia del COVID-19. Método: revisión integradora, realizada en junio de 2020 en los recursos de información Literatura Latinoamericana y del Caribe en Ciencias de la Salud (LILACS), National Library of Medicine National Institutes of Health (PubMed), Portal de Revistas Scientific Eletronic Library Online (SciELO) y Instituto de Ciencia y Tecnología de la Información (Oasis Ibict). Resultados: 14 estudios componen esta revisión. La mayoría de los estudios apuntaron a pruebas, procedimientos de intervención y cirugía para niños con enfermedades cardíacas en tiempos de pandemia; otros discutieron las posibles complicaciones del COVID-19 entre los niños con cardiopatías congénitas. Conclusión: la incipiente producción de estudios y el débil nivel de evidencia denotan un importante vacío de conocimiento hasta el momento, destacando la necesidad de estudios con fuerte evidencia científica para la formulación de guías de atención dirigidas a niños con cardiopatías.

Descriptores: Salud del Ninõ; Niño; Cardiopatías Congénitas; Infecciones por Coronavirus; Pandemia. 


\section{INTRODUCTION}

The outbreak caused by the severe acute respiratory syndrome coronavirus 2 (SARS-CoV-2), the new coronavirus, represents unprecedented challenges for healthcare systems around the world. This virus was responsible for an outbreak of pneumonia that started in December 2019 in Wuhan, China, which spread abruptly around the world, with serious consequences for global health. This was the reason why it was declared a pandemic by the World Health Organization on March 11, 2020(1).

Considering infections previously caused by coronaviruses, it is observed that Coronavirus Disease 2019 (COVID-19), caused by SARS-CoV-2, presents itself as an emerging acute respiratory infectious disease that is highly transmissible among humans, especially from contact direct person-to-person ${ }^{(2)}$. However, despite the significant advances regarding the new coronavirus, knowledge about this disease is still evolving, with neither full information on the natural history nor unquestionable measures for the clinical management of cases of infection in humans ${ }^{(3)}$.

It is known, so far, that the risk factors for evolution with a severe clinical picture and death from infection by the new coronavirus include adults aged 49 years or over and the presence of comorbidities, the latter a characteristic commonly present among children with congenital heart disease $(\mathrm{CHD})^{(4)}$. Despite scientific evidence ${ }^{(5-6)}$ reporting a lower incidence of COVID-19 among children, with a lower rate of complications and deaths, studies ${ }^{(7-8)}$ state that patients with comorbidities, such as cardiovascular diseases, are susceptible to the development of more serious conditions, intensive care and ventilatory assistance.

Moreover, a study shows an increase in the mortality rate due to COVID-19 (13.3\%) among patients with underlying cardiovascular disorders when compared to those without associated comorbidity $(7.6 \%)^{(9)}$. On the other hand, cardiovascular alterations ${ }^{(1)}$ stand out as one of the complications caused by COVID-19, corresponding particularly to the increased risk of morbidity and mortality for this population segment ${ }^{(6)}$

It is understood, therefore, that although the pediatric population is less affected by COVID-19, with a good prognosis, and only $0.2 \%$ of those infected under 19 years of age progress to more severe conditions, children affected by CHD should be considered risky, especially if they have other comorbidities associated with the congenital defect, such as pulmonary hypertension, chronic lung disease and heart failure, further favoring the worsening of the infection ${ }^{(10)}$.

In this directive, the study is justified in that, given the contemporaneity of the COVID-19 pandemic, little is known about the repercussions of this disease in children with CHD, as well as about the treatment and specific care to be developed with them, which leads to a continuous need for updating on the subject among health professionals. Therefore, it is necessary to gather and synthesize the scientific production available on the subject, which favors a better targeting of care in health services for children and their families in pandemic times.

Thus, due to the relevant epidemiological situation and the potential risk of complications caused by the new coronavirus in this population segment, added to the questions that still await clarification, any concrete action in this sphere that aims to add knowledge with a focus on children with heart disease, who require differentiated, qualified and safe care in the face of the pandemic, is privileged.

\section{OBJECTIVE}

To identify the scientific production in health about children with congenital heart disease in COVID-19 pandemic times.

\section{METHOD}

This is an Integrative Literature Review, which enables the identification, synthesis and performance of a broad analysis of the literature on a specific theme ${ }^{(11)}$. To this end, the six steps confluent with the method were followed ${ }^{(12)}$.

The research question was formulated from the search strategy known by the acronym PICo ${ }^{(13)}$, in which: Population (P): children with CHD; Interest (I): health; Context (Co): COVID-19. In this sense, the following research question was formulated: what is addressed about children with CHD in COVID-19 pandemic times in the scientific literature on health?

The second stage consisted of searching for articles in the information resources Latin American and Caribbean Literature in Health Sciences (LILACS), Online Medical Literature Analysis and Retrieval System (MEDLINE), National Library of Medicine National Institutes of Health (PubMed), Portal de Scientific Electronic Library Online Magazines (SciELO) and Brazilian Institute of Information Science and Technology (Oasis Ibict). Controlled terms were used in Portuguese, English and Spanish, associated in pairs and trios through the Boolean operator "AND" and "OR". Search strategies are shown in Chart 1.

The studies were located using the advanced search form in each information resource, in June 2020 . Fully available publications related to the research question and involving children with $\mathrm{CHD}$ at the time of COVID-19 were included. Studies that covered only adults and productions not directed to the focus of the review were excluded. There was no time frame.

The search and selection phase of publications was carried out by two authors, independently. However, the two reviewers collected data on the same day and used the same search strategies, thus performing the reading and evaluation of the titles and abstracts of the articles selected in the information resources, in accordance with the defined inclusion/exclusion criteria. Studies that addressed this topic were chosen for full reading. There were no differences between reviewers regarding the inclusion of manuscripts, both agreed with which studies met the necessary elements to answer the guiding question of this study.

To collect data from the selected studies, an instrument developed by the authors was used, aiming to characterize each production through the following items: identification, year, journal, location, objectives, method, results and interventions (when presented). These data were organized in a database in the Microsoft Excel 2007 program and then analyzed and synthesized by the review authors. To facilitate the identification of the selected studies, an alphanumeric sequence code was used (S1, S2, S3... S14), whose first letter refers to the studies, followed by the Arabic number in the sequence in which the studies were organized. 
Chart 1 - Presentation of descriptors and their intersections in the researched information resources, Brazil, 2020

\begin{tabular}{|c|c|}
\hline Database & Descriptors (crossings) \\
\hline $\begin{array}{l}\text { VHL } \\
\text { regional } \\
\text { portal } \\
\text { (LILACS, } \\
\text { MEDLINE) } \\
\text { PubMed } \\
\text { SciELO } \\
\text { Oasis Ibict }\end{array}$ & 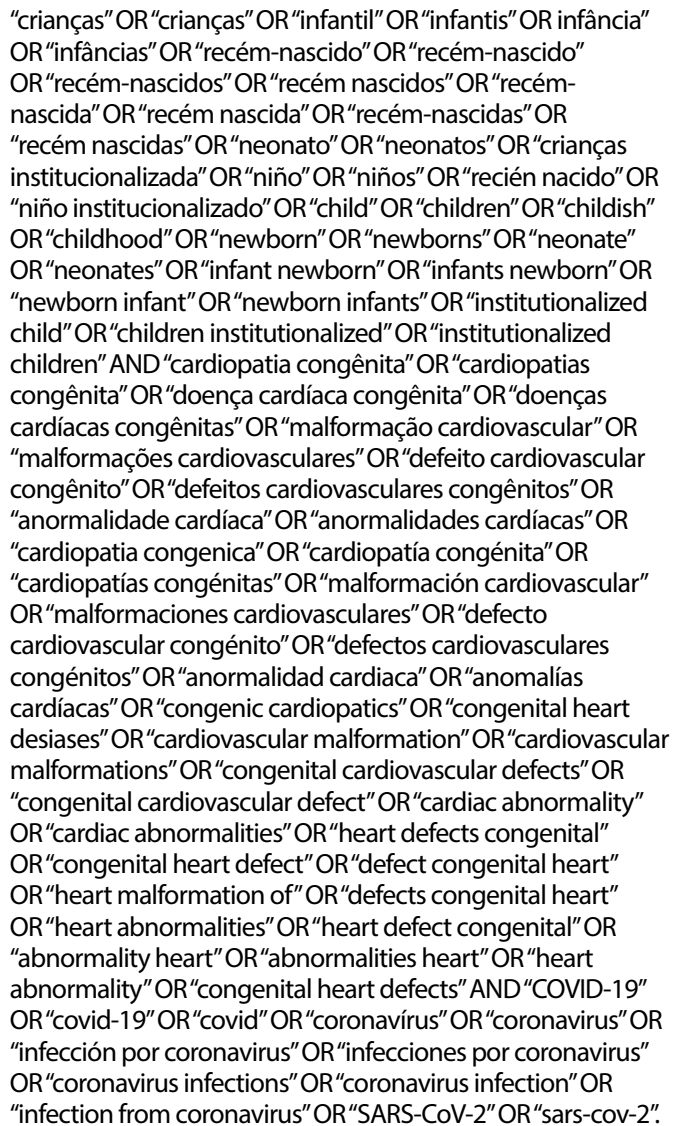 \\
\hline
\end{tabular}

The level of evidence of publications was identified based on the design of each study, guided by the following criteria: I for systematic reviews and meta-analysis of randomized clinical trials; II for randomized clinical trials; III for non-randomized controlled trial; IV for case-control or cohort studies; V for systematic reviews of qualitative or descriptive studies; VI for qualitative or descriptive studies and VII for authoritative opinions and/or expert committee reports. This hierarchy classifies levels I and II as strong, III to V as moderate and VI to VII as weak ${ }^{(14)}$. Based on these criteria, most studies analyzed in this review have a low level of evidence, which is consistent with the recent theme.

\section{RESULTS}

The search resulted in the following distribution among the publications found in each informational resource: LILACS $(n=03)$;
MEDLINE ( $n=02) ;$ PubMed ( $n=25)$, totaling 30 publications. It should be noted that no evidence on the topic was found in the information resources SciELO and Oasis Ibict. Then, the publications found were analyzed, after which duplicated manuscripts by title and abstract were excluded ( $n=02)$. Next, studies were excluded by reading each title, abstract and use of the inclusion criteria. Thus, after reading and final evaluation, 14 studies were included in this review.

To systematize the article selection process, the Preferred Reporting Items for Systematic Reviews and Meta-Analyses (PRISMA) methodology was chosen ${ }^{(15)}$. The steps of this process are described in the form of a flowchart (Figure 1).

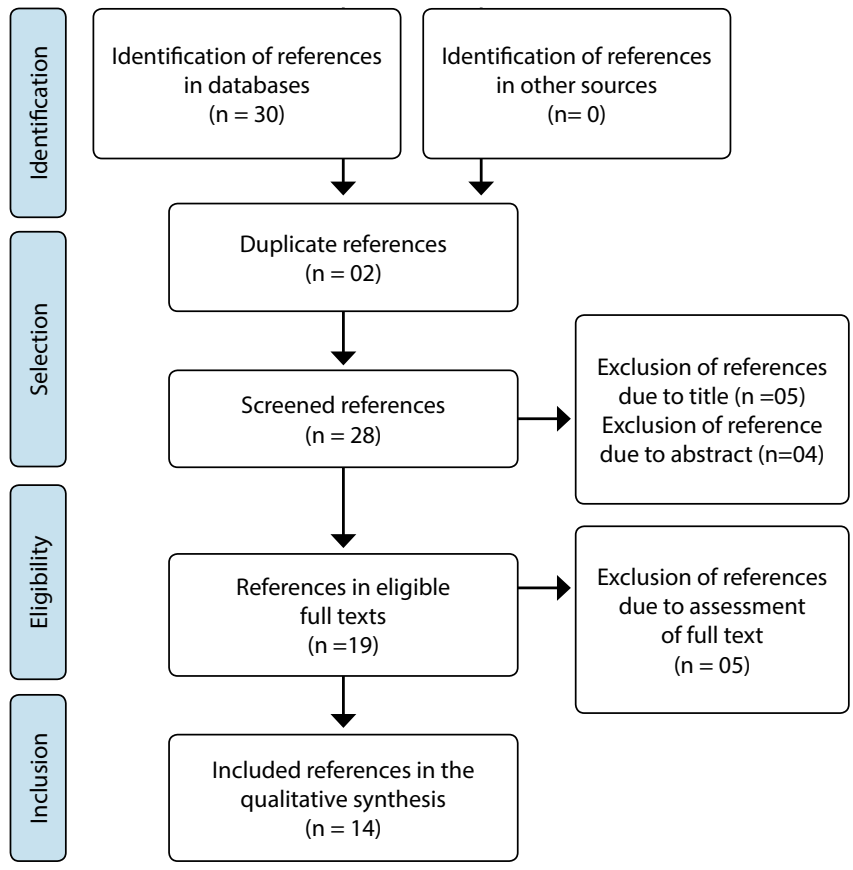

Figure 1- Flowchart of article selection in databases adapted from Preferred Reporting Items for Systematic Review and Meta-Analyses (PRISMA), Brazil, 2020

The 14 selected studies ${ }^{(16-29)}$ were published in 2020. The results of this review revealed that all selected articles were published in international journals in English, totaling four countries, in which the vast majority, 10 articles, was produced in the United States of America (USA), followed by two publications in Italy, one in Europe and another in Australia. As for the methodological design, only one study was a field study with a quantitative approach, eight studies were consensus among experts, two were case studies, one was systematic review and two were review studies. The synthesis of the studies selected for this review is presented in Chart 2.

Chart 2 - Characteristics of selected articles for review according to: identification code of selected articles/title/journal/year/authors/objective/study design and level of evidence, Brazil, 2020

\begin{tabular}{|c|c|c|c|c|c|}
\hline Code & Title & Journal/Year/Authors & Objective & $\begin{array}{l}\text { Study } \\
\text { design }\end{array}$ & $\begin{array}{c}\text { Level of } \\
\text { evidence }\end{array}$ \\
\hline$S 1^{(16)}$ & $\begin{array}{l}\text { Resource Allocation and Decision Making for } \\
\text { Pediatric and Congenital Cardiac Catheterization } \\
\text { During the Novel Coronavirus SARS-CoV-2 } \\
\text { (COVID-19) Pandemic: A U.S. Multi-Institutional } \\
\text { Perspective }\end{array}$ & $\begin{array}{l}\text { The Journal Invasive Cardiology } \\
2020 \\
\text { Morray BH, Gordon BM, Crystal } \\
\text { MA, Goldstein BH, Qureshi AM, } \\
\text { et al. }\end{array}$ & $\begin{array}{l}\text { Describe current standards } \\
\text { and make recommendations } \\
\text { on resource allocation for } \\
\text { cardiac catheterization during } \\
\text { the COVID-19 pandemic. }\end{array}$ & $\begin{array}{l}\text { Consensus } \\
\text { among } \\
\text { experts }\end{array}$ & Level VII \\
\hline
\end{tabular}


Chart 2 (concluded)

\begin{tabular}{|c|c|c|c|c|c|}
\hline Code & Title & Journal/Year/Authors & Objective & $\begin{array}{l}\text { Study } \\
\text { design }\end{array}$ & $\begin{array}{l}\text { Level of } \\
\text { evidence }\end{array}$ \\
\hline$S 2^{(17)}$ & $\begin{array}{l}\text { Cardiac imaging in congenital heart disease } \\
\text { during the coronavirus disease-2019 pandemic: } \\
\text { recommendations from the Working Group on } \\
\text { Congenital Heart Disease of the Italian Society of } \\
\text { Cardiology }\end{array}$ & $\begin{array}{l}\text { Journal of Cardiovascular } \\
\text { Medicine } \\
2020 \\
\text { Sirico D, Castaldi B, Ciliberti P, } \\
\text { Sabatino J, Cazzoli I et al. }\end{array}$ & $\begin{array}{l}\text { Manage the challenges } \\
\text { faced in different imaging } \\
\text { modalities for children with } \\
\text { CHD during the pandemic. }\end{array}$ & $\begin{array}{l}\text { Consensus } \\
\text { among } \\
\text { experts }\end{array}$ & Level VII \\
\hline $\mathrm{S} 3^{(18)}$ & $\begin{array}{l}\text { Recommendations for risk stratified use of cardiac } \\
\text { computed tomography for congenital heart } \\
\text { disease during the COVID-19 pandemic }\end{array}$ & $\begin{array}{l}\text { Journal of Cardiovascular } \\
\text { Computed Tomography } \\
2020 \\
\text { Farooqi KM, Ghoshhajra BB, } \\
\text { Shah AM, Chelliah A, Einstein AJ, } \\
\text { Hlavacek A, Han BK. }\end{array}$ & $\begin{array}{l}\text { Describe strategies for } \\
\text { performing computed } \\
\text { tomography in children } \\
\text { with CHD in pandemic } \\
\text { times. }\end{array}$ & $\begin{array}{l}\text { Consensus } \\
\text { among } \\
\text { experts }\end{array}$ & Level VII \\
\hline$S 4^{(19)}$ & $\begin{array}{l}\text { Specific Considerations for Pediatric, Fetal, } \\
\text { and Congenital Heart Disease Patients and } \\
\text { Echocardiography Service Providers during the } \\
2019 \text { Novel Coronavirus Outbreak: Council on } \\
\text { Pediatric and Congenital Heart Disease Supplement } \\
\text { to the Statement of the American Society of } \\
\text { Echocardiography: Endorsed by the Society of } \\
\text { Pediatric Echocardiography and the Fetal Heart Society }\end{array}$ & $\begin{array}{l}\text { Journal of the American Society } \\
\text { of Echocardiography } \\
2020 \\
\text { Barker PCA, Lewin MB, Donofrio } \\
\text { MT, Altman CA, Ensing GJ, et al. }\end{array}$ & $\begin{array}{l}\text { Present recommendations } \\
\text { for performing } \\
\text { echocardiography, } \\
\text { fetal echocardiography } \\
\text { and transesophageal } \\
\text { echocardiography. }\end{array}$ & $\begin{array}{l}\text { Consensus } \\
\text { among } \\
\text { experts }\end{array}$ & Level VII \\
\hline$S 5^{(20)}$ & $\begin{array}{l}\text { Position Statement on the Management of Cardiac } \\
\text { Electrophysiology and Cardiac Implantable } \\
\text { Electronic Devices in Australia during the } \\
\text { COVID-19 Pandemic: A Living Document }\end{array}$ & $\begin{array}{l}\text { Heart Lung } \\
2020 \\
\text { Kumar S, Haqqani H, Wynn G, } \\
\text { Pathak RK, Lipton J et al. }\end{array}$ & $\begin{array}{l}\text { Report practical } \\
\text { recommendations for } \\
\text { electrophysiology services } \\
\text { and implantable cardiac } \\
\text { electronic devices. } \\
\end{array}$ & $\begin{array}{l}\text { Consensus } \\
\text { among } \\
\text { experts }\end{array}$ & Level VII \\
\hline$S 6^{(21)}$ & $\begin{array}{l}\text { COVID-19: Crisis Management in Congenital Heart } \\
\text { Surgery }\end{array}$ & $\begin{array}{l}\text { Ann Thorac Surg } \\
2020 \\
\text { Stephens EH, Dearani JA, } \\
\text { Guleserian KJ, Overman DM, } \\
\text { Tweddell JS. }\end{array}$ & $\begin{array}{l}\text { Provide guidance for } \\
\text { decision-making regarding } \\
\text { care in congenital heart } \\
\text { surgery during the pandemic. }\end{array}$ & $\begin{array}{l}\text { Consensus } \\
\text { among } \\
\text { experts }\end{array}$ & Level VII \\
\hline$S 7^{(22)}$ & $\begin{array}{l}\text { Considerations for Pediatric Heart Programs during } \\
\text { Coronavirus Disease 2019: Recommendations from } \\
\text { the Congenital Cardiac Anesthesia Society }\end{array}$ & $\begin{array}{l}\text { Anesth Analg } \\
2020 \\
\text { Faraoni D, Caplan LA, DiNardo } \\
\text { JA, Guzzetta NA, Miller-Hance } \\
\text { WC, Latham G, et al. }\end{array}$ & $\begin{array}{l}\text { Present recommendations } \\
\text { for cardiology services for } \\
\text { the care of patients with } \\
\text { CHD in front of COVID- } 19 \text {. }\end{array}$ & $\begin{array}{l}\text { Consensus } \\
\text { among } \\
\text { experts }\end{array}$ & Level VII \\
\hline$S 8^{(23)}$ & COVID-19 FAQ's in Pediatric Cardiac Surgery & $\begin{array}{l}\text { World Journal for Pediatric and } \\
\text { Congenital Heart Surgery } \\
2020 \\
\text { Levy E, Blumenthal J, Chiotos K, } \\
\text { Dearani JÁ. }\end{array}$ & $\begin{array}{l}\text { Recommendations about } \\
\text { the ideal time for surgical } \\
\text { intervention in children with } \\
\text { CHD in face of COVID-19. }\end{array}$ & $\begin{array}{l}\text { Consensus } \\
\text { among } \\
\text { experts }\end{array}$ & Level VII \\
\hline$S 9^{(24)}$ & $\begin{array}{l}\text { Tetralogy of Fallot palliation in a COVID-19 positive } \\
\text { neonate }\end{array}$ & $\begin{array}{l}\text { Journal of Clinical Anesthesia } \\
2020 \\
\text { Salik I, Mehta B. }\end{array}$ & $\begin{array}{l}\text { Present the case of a } \\
\text { newborn with Tetralogy of } \\
\text { Fallot, submitted to surgery, } \\
\text { considered positive for } \\
\text { COVID-19. } \\
\end{array}$ & Case study & Level VI \\
\hline $\mathrm{S} 10^{(25)}$ & $\begin{array}{l}\text { COVID-19 and Congenital Heart Disease: Results } \\
\text { from a Nationwide Survey }\end{array}$ & $\begin{array}{l}\text { Journal of Clinical Medicine } \\
2020 \\
\text { Sabatino J, Ferrero P, Chessa M, } \\
\text { Bianco F, Ciliberti P, et al. }\end{array}$ & $\begin{array}{l}\text { Evaluate clinical } \\
\text { characteristics and } \\
\text { outcomes in patients with } \\
\text { CHD in hospitals in Italy } \\
\text { against COVID-19. }\end{array}$ & $\begin{array}{l}\text { Multicenter, } \\
\text { cross- } \\
\text { sectional, } \\
\text { observational } \\
\text { study }\end{array}$ & Level IV \\
\hline $\mathrm{S} 11^{(26)}$ & $\begin{array}{l}\text { Children's heart and COVID-19: Up-to-date } \\
\text { evidence in the form of a systematic review }\end{array}$ & $\begin{array}{l}\text { European Journal of Pediatric } \\
2020 \\
\text { Sanna G, Serrau G, Bassareo PP, } \\
\text { Neroni P, Fanos V, Marcialis MA. }\end{array}$ & $\begin{array}{l}\text { Summarize cases of } \\
\text { COVID-19 with cardiac } \\
\text { involvement in pediatric } \\
\text { age. }\end{array}$ & $\begin{array}{l}\text { Systematic } \\
\text { review }\end{array}$ & Level I \\
\hline $\mathrm{S} 12^{(27)}$ & $\begin{array}{l}\text { Coronavirus Disease } 2019 \text { (COVID-19) Pandemic } \\
\text { Implications in Pediatric and Adults Congenital } \\
\text { Heart Disease }\end{array}$ & $\begin{array}{l}\text { Journal of the American Heart } \\
\text { Association } \\
2020 \\
\text { Alsaied T, Aboulhosn JA, Cotts } \\
\text { TB, Daniels CJ, Etheridge SP, et al. }\end{array}$ & $\begin{array}{l}\text { Describe the effects } \\
\text { of COVID-19 in the } \\
\text { pediatric and young adult } \\
\text { population with underlying } \\
\text { cardiovascular involvement. }\end{array}$ & $\begin{array}{l}\text { Review } \\
\text { study }\end{array}$ & Level V \\
\hline $\mathrm{S} 13^{(28)}$ & $\begin{array}{l}\text { The cardiovascular burden of coronavirus disease } \\
2019 \text { (COVID-19) with a focus on congenital heart } \\
\text { disease }\end{array}$ & $\begin{array}{l}\text { International Journal of } \\
\text { Cardiology } 2020 \\
\text { Tan W, Aboulhosn J. }\end{array}$ & $\begin{array}{l}\text { Suggest a risk classification } \\
\text { for patients with CHD with } \\
\text { potential implications and } \\
\text { risk for COVID-19. } \\
\end{array}$ & $\begin{array}{l}\text { Review } \\
\text { study }\end{array}$ & Level VII \\
\hline S14 & $\begin{array}{l}\text { COVID-19 in a pediatric heart transplant recipient: } \\
\text { Emergence of donor-specific antibodies }\end{array}$ & $\begin{array}{l}\text { The Journal of Heart and Lung } \\
\text { Transplatation } 2020 \text { Russell MR, } \\
\text { Halmon NJ, Alejos JC, Salem MM, } \\
\text { Reardon LC. }\end{array}$ & $\begin{array}{l}\text { Report the case of a child who } \\
\text { tested positive for COVID-19 } \\
\text { after heart transplantation. }\end{array}$ & Case study & Level VI \\
\hline
\end{tabular}


To better ratify the findings and discuss them in a reasoned manner, through the convergence of subjects, the results were categorized into two units of analysis, namely: Examinations, interventional procedures and surgery in children with congenital heart disease in pandemic times; Complications of COVID-19 among children with congenital heart disease.

Unit 1: Examinations, interventional procedures and surgery in children with congenital heart disease in pandemic times

In this unit, nine studies ${ }^{(16-24)}$ reported guidelines/recommendations based on consensus among experts for performing imaging tests, intervention procedures and surgery in children with $\mathrm{CHD}$ in COVID-19 pandemic times.

$\mathrm{S} 1^{(16)}$ highlights that, in regions considered epicenters of $\mathrm{CO}-$ VID-19, interventionist practice patterns have changed due to the risk of transmission through direct contact with children and their families, in addition to the limited availability of personal protective equipment (PPE) in many US hospitals, as well as ventilators, making it essential to only perform tests considered to be emergency or very urgent.

In this perspective, the study ${ }^{(16)}$ reports the creation of a classification for performing cardiac catheterizations according to clinical status. Thus, emergency procedures must be performed in a timely manner, those classified as semi-elective, must be scheduled within one to three months, and electives can be postponed for up to three months. However, it is noteworthy that it is important to recognize that each patient is unique and these categories should not replace clinical judgment.

$\mathrm{S} 2^{(17)}$ points out recommendations for performing imaging tests, such as tomography, echocardiography and magnetic resonance (MR) in suspected or confirmed cases of COVID-19. Thus, echocardiography in newborns (NBs) with a strong clinical suspicion of congenital heart disease (CHD) or prenatal diagnosis of critical CHD has top priority; patients with known coronary artery disease, or in the face of a change in medical management, or in the face of a recently performed intervention, is classified as a medium priority; Scheduled outpatient follow-up has low priority for the exam.

According to $\mathrm{S} 3^{(18)}, \mathrm{MR}$ is rarely considered a mandatory test, however, it is highlighted that it may be necessary in view of the development of complications caused by COVID-19, such as myocarditis. In these cases, the exam must be performed considering risk/benefit according to the hemodynamic status of the patients and the therapeutic impact of the exam.

These findings are similar to S3(18) developed in the USA, compared to the performance of computed tomography (CT), which created a stratification due to the need to perform this in three levels, namely: level 1 - urgent, patients need images to plan the intervention in days or weeks in order to optimize the treatment, waiting time less than seven days; level 2 - semiurgent, the exam must be performed within one to three months; level 3 - non-urgent outpatient clinic and routine surveillance to monitor the disease without any expectation of intervention can wait from three to six months or more.

Regarding the performance of transesophageal echocardiography (TEE), $\mathrm{S} 4^{(19)}$ points out that specific recommendations were also created in view of the imminent risks of transmission, since children, despite the lower overall prevalence of this infection, paradoxically, when infected, present high viral loads in the nasopharynx and secretions, which can create an increased risk of exposure for the team and the community

To perform fetal echocardiography, the study ${ }^{(19)}$ highlights the following criteria: if assessment of the fetus can be confirmed through combined experience between physicians (fetal cardiologist and obstetrician), examination is postponed; for patients at moderate risk, testing should be postponed to a later date when the risk of SARS-CoV-2 contamination is diminished, or after 28 weeks' gestation; for high-risk patients or urgent clinical indications, schedule and perform the exam immediately ${ }^{(19)}$.

$\mathrm{S}^{(20)}$, developed in Australia, points to management for cardiac electrophysiology and implantation of electronic cardiac devices during the pandemic. Thus, for patients with an implanted device, remote monitoring was established, and for those who did not have it, installation was recommended according to clinical condition. It is also noteworthy that monitoring must take place remotely, and medical consultations must be replaced by telemedicine, always guided by patients' clinical condition. This action aims to reduce the spread of the virus not only to the team, but to the community in general.

$S 6$ and $S 7^{(21-22)}$ describe guidelines for decision-making in view of the unique challenges related to cardiac surgery that, even during the pandemic, children with CHD continue to require care. In this directive, it is suggested that surgery be performed only in the most urgent cases, a fact that holds great challenges when it comes to CHD. Thus, in urgent surgical cases, some factors must be individually assessed, including: material resources involved, such as a respirator and length of stay in the Intensive Care Unit (ICU); clinical status of patients versus risk of postponing surgery; risk of exposure for the patient, family and staff; comorbidities and complexity of the procedure; lack of qualified professionals; the security of patients social and clinical situation if surgery is postponed.

Also in this aspect, the same studies recommend restricting elective procedures, leaving it under the responsibility of the multidisciplinary committees or teams to prioritize urgent and emergency cases, considering the hospital capacity and the local resources available during the COVID-19 pandemic.

Another finding of this review refers to the ideal time for correction of CHD in patients positive for COVID-19. So far, there is still no evidence to indicate the ideal time; however, $S 8^{(23)}$ advises that surgery should be postponed until the symptoms have ceased and that testing for COVID-19 is repeated after 14 days with a negative result.

The same study ${ }^{(23)}$ mentions the approach of newborns from COVID-19-positive mothers, who underwent surgical correction in the first weeks of life, reporting that there is no consensus on this issue and who so far, there is little evidence to suggest the vertical transmission. However, they describe the risk of transmission soon after birth.

This reality was highlighted in $59^{(24)}$, which reported the experience of surgical correction in NBs diagnosed in utero with Tetralogy of Fallot, even positive for COVID-19 one week after birth. According to the study, transmission took place in the postnatal period, when contact with the mother who also tested positive for COVID-19, after presenting fever and shortness of breath in the postpartum period. 


\section{Unit 2: Complications of COVID-19 among children with} congenital heart disease

In this unit, five studies ${ }^{(25-29)}$ showed that children with $\mathrm{CHD}$ are at high risk for the development of secondary cardiovascular complications, with a worsening of the clinical picture compared to COVID-19.

$\mathrm{S} 10^{(25)}$, developed in eight cardiology centers in Italy, followed, for four weeks, 76 patients, including children and adults, with CHD with a positive diagnosis for COVID-19, identifying that, of the 76 cardiac patients with COVID-19, $9 \%$ had heart failure, 3\% had arrhythmias, $3 \%$ had stroke, $3 \%$ had pulmonary hypertension and $1 \%$ had myocardial injury. It has been shown that patients with underlying cardiovascular disease and other comorbidities are more likely to suffer myocardial damage during the course of COVID-19. However, no deaths were observed and most remained asymptomatic and uncomplicated.

Similar data were found in $\mathrm{S} 11^{(26)}$, when it concluded that, although COVID-19 infection in childhood is less common and accompanied by mild symptoms, when compared to adults, it does not occur without cardiac involvement, especially in patients with a history of CHD. It was also evidenced that, in NBs and children with previous cardiac surgery, it is related to the most severe form, requiring intensive care, intubation and mechanical ventilation, but with no reported mortality. $\mathrm{S} 12^{(27)}$ supports the same statement.

Considering that patients with CHD represent a risk group and, therefore, may have more serious complications and, due to the incipient production so far of studies that robustly detail the risk of cardiovascular complications in this population, $\mathrm{S} 13^{(28)}$ suggests a risk classification based on the anatomy of CHD and patients' clinical condition. Thus, patients with complex CHD, such as unrepaired and/or palliated cyanotic heart disease, with hemodynamic repercussions, can be considered at high risk of complications related to COVID-19 infection, based on the decrease in functional reserve.

Another issue that emerged from $\mathrm{S} 14^{(29)}$ was the case report of a COVID-19-positive child one year after heart transplantation. The study concludes that the patient, despite having complications, was discharged with a good prognosis.

\section{DISCUSSION}

Corroborating the findings of this review, medical societies in Brazil and around the world have uniformly positioned themselves, recommending that patients in a stable clinical condition should stay at home ${ }^{(30-31)}$. Likewise, for interventional procedures, such as cardiac catheterization, the Brazilian Society of Hemodynamics and Interventional Cardiology recommends postponing elective procedures, testing patients with express indication, in addition to providing adequate PPE for each case ${ }^{(30)}$.

In this perspective, the Inter-American Society of Cardiology (IASC) ${ }^{(32)}$ recommends that echocardiography should focus on determining the presence or absence of heart disease and advises not to obtain regular obstetric parameters until the current health situation is resolved. In addition, it proposes some precautions regarding the examination, such as: initial assessment: focusing only on cardiac assessment; follow-up echo: assess the main points of regression or evolution of the disease; fetal development follow-up echo: whenever possible, should be rescheduled. However, in the face of diagnoses such as Transposition of the Great Arteries (TGA), Double Outlet Right Ventricle (DORV), pulmonary atresia, among other cyanotic heart diseases, follow-up must be maintained, recognizing that adjustments in these decisions must be evaluated by each institution, individually ${ }^{(33)}$.

In this regard, the Department of Congenital Heart Diseases and Pediatric Cardiology (DCHD/PC) in Brazil corroborates the findings of this review when it reports that, in addition to urgent exams, all elective exams in clinically stable individuals, whose clinical and functional evolution will not worsen in the next three months, they should be postponed, as long as each case is evaluated individually, weighing the risk of COVID-19 and the damage caused to patients by the postponement of treatment for heart disease $\mathrm{e}^{(31)}$.

Moreover, the DCHD/PC recommends that surgical or interventional procedures should be maintained in front of patients diagnosed with severe heart disease, with significant clinical and hemodynamic repercussions, or in view of the risk of imminent clinical deterioration, noting that, in many severe cases, the risk of CHD outweighs the risk of COVID-19, as well as the damage caused by postponing treatment ${ }^{(31)}$.

Faced with a disease still in evolution, it is testified, through the findings, that the professional associations/societies seek to guide the conduct of the health of children with heart disease so that interventional, surgical procedures and imaging exams should privilege the most serious cases, safeguarding stable patients, denoting the particular interest of this specialty in determining actions and interventions necessary for the protection of this age group.

The same could be observed in Brazil, when the same criterion was adopted in stratifying patients regarding the need for the examination or not. However, in this regard, it is important to highlight the difficulty encountered by health professionals in determining which procedure should be performed and in which patients, considering the pathophysiology and clinical condition presented by each patient with CHD. Emergency stratifications must be performed promptly, as well as elective catheterization, which can wait for a period greater than or equal to ninety days, is easy to define. However, the great impasse is concentrated on patients stratified as semi-elective, with the need to perform it in less than ninety days, in order to avoid deterioration and clinical deterioration ${ }^{(1)}$. A case-by-case discussion by the entire team involved in the health care of children with heart disease is urgently needed to decide whether or not to perform the procedure.

As a way to assist and guide health professionals in the indication and performance of procedures, some criteria were recently published by the Society for Cardiovascular Angiography and Interventions (SCAI), enabling adaptations through discussions between the authors of these recommendations to the national reality. However, the need to individually assess each patient and procedure against the reality of each institution is highlighted ${ }^{(1)}$.

Therefore, the existence of a defined action protocol for health services goes beyond identifying which children will or will not undergo the intervention procedure. Such action provokes a reflection on the ways of acting in front of children with heart disease in pandemic times caused by COVID-19, which is current and in production, whose actions and interventions are sometimes restricted in face of the imminent risks caused by COVID - 19 . 
Another finding in this investigation mentions the approach of newborns from COVID-19-positive mothers undergoing surgical correction in the first weeks of life. On this aspect, there is still no evidence on vertical transmission ${ }^{(31,34)}$. Small case series did not show the presence of the virus in the placenta, amniotic fluid in umbilical cord blood or breast milk. Therefore, vertical transmission of this infection, although it seems possible, has not been proven. Thus, it is believed that the main route of transmission occurs through droplets through infected caregivers or through contact with contaminated biological material from the mother to $\mathrm{NBs}^{(31,35)}$.

Thus, by all health institutions, the NB from a COVID-19 positive mother should be considered under investigation, considering that it is reasonable to separate the babies from the mothers if the surgical procedure for correction of CHD is indicated, in order to avoid postnatal infection. It is also highlighted the need to perform serial tests in NBs, as recommended by some specialists ${ }^{(36)}$.

In light of current knowledge, it is known that patients with comorbidities are part of a risk group for COVID-19, as well as children with CHD. On the other hand, children, when infected, can be asymptomatic and present mild clinical manifestations and usually with a good prognosis ${ }^{(37)}$.

This position is in line with DCHD/PC in Brazil, when it reports a lower incidence of the disease in children, with a lower rate of complications and death. However, although the literature reports the emergence of complications in patients with underlying CHD, it emphasizes that the real risk of this infection in this population segment and its potential complications are so far unknown ${ }^{(31)}$.

However, the need for health services to recognize two distinct groups of cardiac patients as a way of acting in the face of COVID-19 is highlighted, namely: CHD or acquired without hemodynamic repercussions and which were corrected by surgery or clinically stable interventional catheterization. The risk is similar to that of the pediatric population in general, but children with CHD or acquired who have significant hemodynamic repercussions and who have already undergone surgical correction, but maintain signs of hemodynamic instability, are a risk group for greater attention by health services compared to COVID-19, as it may present worsening of ventilatory conditions earlier and more intensely in the face of this infection ${ }^{(31)}$.

Although one of the evidences has reported the case of patients transplanted with COVID-19, so far, there are no specific studies on this aspect. It is known that this group is at high risk for viral infections corresponding to the state of immunosuppression to which they are submitted. From this perspective, it is recommended to avoid contact with people suffering from the flu, as well as places of agglomeration, as it is understood that the development of COVID-19 in transplanted children may develop more severe conditions. The same position is adopted by
US transplant programs, considering that heart transplantation is an emergency surgical procedure. However, it is recommended that, given the need to perform such a procedure, patients should be tested for COVID-19; if patients test positive and present signs of severe acute respiratory syndrome, the procedure should be postponed until the clinical condition improves ${ }^{(31)}$.

\section{Study limitations}

The absence of moderate or strong scientific evidence in the literature on the subject stands out, a condition justified by the fact that it is an emerging disease, but which indicates the need for updating when new studies are conducted.

\section{Contributions to nursing, health, and public policies}

This study contributes to care and management practice in health, as it identified current and little explored evidence about COVID-19, especially in this specialty of pediatric cardiology nursing, in addition to supporting the adoption of strategies and behaviors identified as a way to guide decision-making by health professionals in hospitals regarding the care of children with CHD against COVID-19 regarding examinations, interventional procedures and surgery in this population group. It is important to emphasize the role of nurses in guiding the nursing team and family caregivers, both at an outpatient and in-patient level, on the examinations, surgeries and procedures to which children are submitted.

Furthermore, this review allowed us to understand that children with CHD are at high risk for the development of cardiovascular complications secondary to the worsening of the clinical picture in the face of COVID-19, which imposes the need for careful assessment and differentiated care in pandemic times.

\section{CONCLUSION}

The findings indicated that, so far, scientific production has two main focuses on the theme of this review: examinations, interventional procedures and surgery in children with heart disease in pandemic times and possible complications of COVID-19 among this population group.

The incipient production of studies in Brazil and in the world and the absence of stronger scientific evidence denote an important knowledge gap so far. Thus, there is a need for further research with a strong level of evidence, especially in nursing, for the formulation of care guidelines for this population group, which contribute to the recovery of health condition and mitigation of possible complications of COVID-19 in children with CHD and favor healthy child development during and post-pandemic as an inalienable right to health in a safe and qualified manner.

\section{REFERENCES}

1. Neves JR, Bodini AL, Pilla CB, Bergman F, Simões LC, Hincapié MJ, et al. Situation analysis of percutaneous interventions in congenital heart defects during COVID-19 pandemic in Brazil. Current recommendations by Sociedade Brasileira de Hemodinâmica e Cardiologia Intervencionista and future planning. J Transcat Intervent. 2020;28:eA202009. https://doi.org/10.31160/ JOTCI202028A202009 
2. Li Q, Guan X, Wu P, et al. Early transmission dynamics in Wuhan, China, of novel coronavirus-infected pneumonia. N Engl J Med. 2020;382:1199-1207. https://doi.org/10.1056/NEJMoa2001316

3. McIntosh K, Bloom A. Novel Coronavirus (2019-nCov)[Internet]. 2020[cited 2020 Jun 29]. UpToDate. Available from: https://www.uptodate. com/contents/coronavirus-disease-2019-covid-19-epidemiology-virology-clinical-features-diagnosis-and-prevention

4. Ministério da Saúde (BR). Coronavírus Brasil[Internet]. Brasília, DF: Ministério da Saúde. 2020 [cited 2020 Jun 18]. Available from: covid. saude.gov.br

5. Ludvigsson JF. Systematic review of COVID-19 in children shows milder cases and a better prognosis than adults. Acta Paediatr. 2020;109:1088-95. https://doi.org.br/10.1111/apa.15270

6. Li B, Yang J, Zhao F, Zhi L, Wang X, Liu L, et al. Prevalence and impact of cardiovascular metabolic diseases on COVID-19 in China. Clin Res Cardiol. 2020;109:531-8. https://doi.org/10.1007/s00392-020-01626-9

7. Safadi MAP. The intriguing features of COVID-19 in children and its impact on the pandemic. J Pediatr. 2020;96(3):265-8. https://doi. org/10.1016/j.jped.2020.04.001

8. Epicentro. Istituto Superiore di Sanità. Characteristics of COVID-19 patients dying in Italy [Internet]. 2020 [cited 2021 Aug 17] Available from: https://www.epicentro.iss.it/en/coronavirus/sars-cov-2- analysis-of-deaths

9. Guo T, Fan Y, Chen M, Wu X, Zhang L, He T, et al. Cardiovascular implications of fatal outcomes of patients with coronavirus disease 2019 (COVID-19). JAMA Cardiol. 2020;5(7):811-8. https://doi.org/10.1001/jamacardio.2020.1017

10. Castagnoli R, Votto M, Licari A, Brambilla I, Bruno R, Perlini S, et al. Severe acute respiratory syndrome coronavirus 2 (SARS-CoV-2) infection in children and adolescents: a systematic review. JAMA Pediatr. 2020;174(9):882-9. https://doi.org/10.1001/jamapediatrics.2020.1467

11. Silva CC, Savian CM, Prevedello BP, Zamberlan C, Dalpian DM, Santos BZ. Access and use of dental services by pregnant women: an integrative literature review. Ciênc Saude Coletiva. 2020;25(3):827-35. https://doi.org/10.1590/1413- 81232020253.01192018

12. Souza LMM, Marques-Vieira CMA, Severino SSP, Antunes AV. The methodology of integrative review of literature in nursing. Rev Invest Enferm. 2017;2(21):17-26. Available from: http://hdl.handle.net/20.500.12253/1311

13. Peters MDJ, Godfrey CM, McInerney P, Soares CB, Khalil H, Parker D. The Joanna Briggs Institute reviewers' manual 2015: methodology for JBI scoping reviews [Internet]. 2015 [cited 2020 May 2]. Available from: https://nursing.lsuhsc.edu/JBI/docs/ReviewersManuals/Scoping-.pdf

14. Melnyk BM, Fineoutoverholt E. Evidence-based practice in nursing \& healthcare: a guide to best practice. 4 ed. Philadelphia: Wolters Kluwer Health; 2019. 1157p.

15. Moher D, Liberati A, Tetzlaff J, Altman DG, Altman D, Antes G, et al. (2009). Preferred reporting items for systematic reviews and metaanalyses: the PRISMA statement. PLoS Medicine. 2009;6(7):1-6. https://doi.org/10.1371/journal.pmed.1000097

16. Morray BH, Gordon BM, Crystal MA, Goldstein BH, Qureshi AM, Torres AJ, et al. Resource Allocation and Decision Making for Pediatric and Congenital Cardiac Catheterization During the Novel Coronavirus SARS-CoV-2 (COVID-19) Pandemic: A U.S. Multi-Institutional Perspective. J Invasive Cardiol[Internet] 2020 [cited 2020 Jun 29];32(5):E103-E109. Available from: https://www.invasivecardiology.com/sites/ invasivecardiology.com/files/articles/images/E103-E109\%20Morray\%20JIC\%202020\%20May\%20wm.pdf

17. Sirico D, Castaldi B, Ciliberti P, Sabatino J, Cazzoli I, Secinaro A, et al. Cardiac imaging in congenital heart disease during the coronavirus disease-2019 pandemic: recommendations from the Working Group on Congenital Heart Disease of the Italian Society of Cardiology. Working Group on Congenital Heart Disease of the Italian Society of Cardiology. J Cardiovasc Med (Hagerstown). 2020;21 (7):467-71. https://doi. org/10.2459/JCM.0000000000000990

18. Farooqi KM, Ghoshhajra BB, Shah AM, Chelliah A, Einstein AJ, Hlavacek A, et al. Recommendations for risk stratified use of cardiac computed tomography for congenital heart disease during the COVID-19 pandemic. J Cardiovasc Comput Tomogr. 2020;9:S1934-5925(20)30176-3. https://doi.org/10.1016/j.jcct.2020.06.003

19. Barker PCA, Lewin MB, Donofrio MT, Altman CA, Ensing GJ, Arya B, et al. Specific Considerations for Pediatric, Fetal, and Congenital Heart Disease Patients and Echocardiography Service Providers during the 2019 Novel Coronavirus Outbreak: Council on Pediatric and Congenital Heart Disease Supplement to the Statement of the American Society of Echocardiography: Endorsed by the Society of Pediatric Echocardiography and the Fetal Heart Society. J Am Soc Echocardiogr. 2020;33(6):658-65. https://doi.org/10.1016/j.echo.2020.04.005

20. Kumar S, Haqqani H, Wynn G, Pathak RK, Lipton J, Mahajan R, et al. Position Statement on the Management of Cardiac Electrophysiology and Cardiac Implantable Electronic Devices in Australia during the COVID-19 Pandemic: A Living Document. Cardiac Society of Australia and New Zealand (CSANZ) Heart Rhythm Council COVID-19 Pandemic Working Group. Heart Lung Circ. 2020;29(6):e57-e68. https://doi.org/10.1016/j.hlc.2020.04.001

21. Stephens EH, Dearani JA, Guleserian KJ, Overman DM, Tweddell JS, Backer CL, et al. COVID-19: Crisis Management in Congenital Heart Surgery. Ann Thorac Surg. 2020;14:S0003-4975(20)30540-. https://doi.org/10.1016/j.athoracsur.2020.04.001

22. Faraoni D, Caplan LA, DiNardo JA, Guzzetta NA, Miller-Hance WC, Latham G, et al. Considerations for Pediatric Heart Programs during Coronavirus Disease 2019: recommendations from the Congenital Cardiac Anesthesia Society. Anesth Analg. 2020;131(2):403-409. https:// doi.org/10.1213/ANE.0000000000005015

23. Levy E, Blumenthal J, Chiotos K, Dearani JA. COVID-19 FAQ's in Pediatric Cardiac Surgery. World J Pediatr Congenit Heart Surg. 2020;11(4):485-7. https://doi.org/10.1177/2150135120924653

24. Salik I, Mehta B. Tetralogy of Fallot palliation in a COVID-19 positive neonate. J Clin Anesth. 2020;66:109914. https://doi.org/10.1016/j. jclinane.2020.109914 
25. Sabatino J, Ferrero P, Chessa M, Bianco F, Ciliberti P, Secinaro A, et al. COVID-19 and Congenital Heart Disease: results from a Nationwide Survey. J Clin Med. 2020;9(6):E1774. https://doi.org/10.3390/jcm9061774

26. Sanna G, Serrau G, Bassareo PP, Neroni P, Fanos V, Marcialis MA. Children's heart and COVID-19: Up-to-date evidence in the form of a systematic review. Eur J Pediatr. 2020;179(7):1079-87. https://doi.org/10.1007/s00431-020-03699-0

27. Alsaied T, Aboulhosn JA, Cotts TB, Daniels CJ, Etheridge SP, Feltes TF, et al. Coronavirus Disease 2019 (COVID-19) Pandemic Implications in Pediatric and Adult Congenital Heart Disease. J Am Heart Assoc. 2020;9(12):e017224. https://doi.org/10.1161/JAHA.120.017224

28. Tan W, Aboulhosn J. The cardiovascular burden of coronavirus disease 2019 (COVID-19) with a focus on congenital heart disease. Int J Cardiol. 2020; 309:70-7. htpp://doi:10.1016/j.ijcard.2020.03.063.

29. Russell MR, Halnon NJ, Alejos JC, Salem MM, Reardon LC. COVID-19 in a pediatric heart transplant recipient: Emergence of donor-specific antibodies. J Heart Lung Transplant. 2020:S1053-2498(20)31532-1. https://doi.org/10.1016/j.healun.2020.04.021

30. Falcão BA, Botelho RV, Sarmento-Leite RE, Costa RA. Update on SBHCl positioning about COVID-19 pandemic. J Transcat Intervenc. 2020;28:eA202004. https://doi.org/10.31160/ JOTCI202028A202004

31. Sociedade Brasileira de Pediatria (SBP). Departamento de Cardiopatias Congênitas e Cardiologia Pediátrica. Nota de alerta. A criança com cardiopatia nos tempos de COVID-19 - Posicionamento oficial conjunto [Internet]. São Paulo: SBP; 2020 [cited 2020 Jun 20]. Available from: https://www.sbp.com.br/fileadmin/user_upload/22421b-Nota_Alerta_-_Crianca_Cardiopatia_nos_tempos_COVID-19.pdf

32. ASE COVID-19 resource webpage[Internet]. 2020. [cited 2020 Jul 18]. Available from: https://www.asecho.org/covid-19-resources/

33. Pérez F, Biancolini F, Veja B, Vázquez E, Madrid A, Bueno N, et al. Recomendaciones Ecocardiograma Fetal para el cuidado y atención de pacientes embarazadas frente a la pandemia COVID 19 [Internet]. 2020. [cited 2020 Jun 29]. Available from: http://www.siacardio.com/ novedades/covid-19/recomendaciones-ecocardiograma-fetal-para-el-cuidado-y-atencion-de-pacientes-embarazadas-frente-a-la-pandemia

34. Schwartz DA. An Analysis of 38 Pregnant Women with COVID-19, Their Newborn Infants, and Maternal-Fetal Transmission of SARS-CoV-2: Maternal Coronavirus Infections and Pregnancy Outcomes. Arch Pathol Lab Med. 2020. https://doi.org/10.5858/arpa.2020-0901-SA

35. Sociedade Brasileira de Pediatria (SBP). Recomendações para Assistência ao Recém-Nascido na sala de parto de mãe com COVID-19 suspeita ou confirmada: Atualização 2 [Internet]. 2020 [cited 2020 Jun 24]. Available from: https://www.sbp.com.br/fileadmin/user_ upload/22499c-NAAssist_RN_SalaParto_de_mae_com_COVID-19.pdf

36. Zhu H, Wang L, Fang C, Peng S, Zhang L, Chang G, et al. Clinical analysis of 10 neonates born to mothers with 2019-nCoV pneumonia. Transl Pediatr 2020;9(1):51-60. https://doi.org/10.21037/tp.2020.02.06

37. Cao Q, Chen Y, Chen C, Chiu C. SARS-CoV-2 infection in children: transmission dynamics and clinical characteristics. J Formos Med Assoc. 2020;119(3):670-673. https://doi.org/10.1016/j.jfma.2020.02.009 